\title{
FECUNDITY, PARITY, AND ADULT FEEDING RELATIONSHIPS AMONG NYSSORHYNCHUS MALARIA VECTORS FROM VENEZUELA
}

\author{
L. P. LOUNIBOS \& JAN CONN*/ ${ }^{+}$
}

\begin{abstract}
Florida Međical Entomology Laboratory, University of Florida, 2009 th Street S. E., Vero Beach, FL 32962
USA *Instituto de Zoologia Tropical, Universidad Central de Venezuela, Apartado 47058, Caracas 1041-A, Venezuela
\end{abstract}

Relative to their pre-engorgement weights, nulliparous Anopheles nuneztovari consumed significantly smaller blood meals than A. marajoara, A. triannulatus or A. aquasalis. When females were deprived of sugar before blood feeding, only one-quarter of A. nuneztovari, but more than two-thirds of A. marajoara, A. triannulatus and A. aquasalis matured eggs.

Sugar feeding before blood, or two successive blood meals by sugar-deprived females, increased the proportion of nulliparous A. nuneztovari which developed eggs, but not significantly so. Nearly all individuals of nulliparous, sugar-fed A. marajoara, A. triannulatus and A. aquasalis matured eggs after one blood feeding.

Among A. nuneztovari, A. marajoara and A. aquasalis that matured some eggs in the laboratory, there were no positive correlations between the number of eggs developed and relative blood meal size. However, blood meals larger than the mean size significantly increased the chance that A. nuneztovari would develop some eggs. Mean fecundities of gravid A. nuneztovari and A. marajoara reared in the laboratory were significantly lower than those of the same species captured at human bait in nature. Post-engorgement access to sugar by A. nuneztovari (captured at human bait) did not influence fecundity, but significantly enhanced survivorship and the proportion of individuals which retained eggs.

Release-recapture experiments revealed that relatively small blood meals are typical of A. . nuneztovari only during the first gonotrophic cycle. We suggest that multiple blood feeding, seemingly necessary for most A. nuneztovari to develop a first clutch of eggs, may increase the probability of infection with Plasmodium vivax where this mosquito species is a primary vector.

Key words: Anopheles (Nyssorhynchus) - Venezuela - mosquito - blood meal size - fecundity - parity egg development

It is well established that some important vectors of human malaria consume blood two or more times within a gonotrophic cycle. Brengues \& $\mathrm{Coz}$ (1973) reported that $42 \%$ of Anopheles gambiae (s. s.) and $63 \%$ of $A$. funestus in West Africa needed two or more

This research was supported in part by U.S. National Institutes of Health Fellowship 1 FO6 TWO1422 to LPL and by grant MVR-72 (Y. Rubio, PI) from BOSTID of the U. S. National Academy of Sciences. This is Florida Agricultural Experiment Stations Journal Series No. R-00885.

+ Present address: U. S. D. A., Medical and Veterinary Entomology Research Laboratory, P. O. Box 14565, Gainesville, FL 32604 USA.

Received 7 August 1990.

Accepted 27 September 1990. blood feeds to develop their first egg batch and Gillies (1954) documented this phenomenon among nearly all, newly emerged $A$. gambiae (s. 1.) from Tanzania. In the sudanese savanna, an increase in the proportion of $A$. gambiae (s. 1.) and $A$. funestus feeding twice per cycle occurred during the dry season (Molineaux \& Gramiccia, 1980) when environmental conditions place more stress upon mosquito survival. Among A. culicifacies in Pakistan, females may take as many as three blood meals from emergence to first oviposition (Reisen \& Aslamkhan, 1976). For most $A$. gambiae (s. s.) and $A$. culicifacies, the first blood feeding occurs before insemination (Gillies, 1954; Brengues \& Coz, 1973; Reisen \& Aslamkhan, 1976). 
The consumption of several blood meals per ovarian cycle is usually attributed to weak or partial feeds (Reisen \& Aslamkhan, 1976) caused by disturbances such as defense by the host (Burkot, 1988). The frequency of contact with the host by some mosquito species may also be influenced by larval diet (Grimstad \& Haramis, 1984). To our knowledge, scant consideration has been given to the possibility that genetic characteristics may determine the number of feeds per gonotrophic cycle.

The increased frequency of host contact at tributable to multiple blood meals may raise the vectorial capacity (VC) of a mosquito population. Of the three determinants of $\mathrm{VC}$ in the Ross-MacDonald equation for malaria transmission, host contact is a squared factor, increasing its contribution to $\mathrm{VC}$ relative to mosquito density and longevity (Macdonald, 1957). While interrupted feeds do not, per se, increase the transmission rate of malaria from man to mosquito (Burkot, 1988), Ponnudarai et al. (1989) reported that a non-infective bloodmeal following an infective one increased the sporozoite load in the salivary glands of A. stephensi.

We focus in this study on relationships between the size of the blood meal and egg development, and their implications for multiple blood feeding among four species of the anopheline subgenus Nyssorhynchus. Two of these species are important malaria vectors in Venezuela: A. nuneztovari in the west (Gabaldon, 1981 ) and $A$. aquasalis on the coast (Hamon et al., 1970). Both $A$. triannulatus and $A$. marajoara infected with Plasmodium vivax have been captured in Brazil (Arruda et al., 1986), and may be secondary vectors of human malaria in various neotropical countries (Faran, 1980; Linthicum, 1988).

\section{MATERIALS AND METHODS}

Mosquito collections, identifications and maintenance - Female Nyssorhynchus were collected from November 1988 through October 1989 at human bait between 1900 and $2300 \mathrm{~h}$ at Guaquitas and El Achote, Tachira State $\left(7.5^{\circ} \mathrm{N}, 71.7^{\circ} \mathrm{W}\right)$, Venezuela. A single collection of Anopheles (Nyssorhynchus) aquasalis was made at human bait in Santa $\mathrm{Fe}$, Sucre State $\left(10.3^{\circ} \mathrm{N}, 64.4^{\circ} \mathrm{W}\right)$, Venezuela in February 1990. Mosquitoes that engorded on the blood of collectors were maintained overnight in humidified, 0.5-litre cups covered with tulle. The following morning, the females were lightly anesthetized with chloroform and identified to species with dichotomous keys (Faran, 1980; Faran \& Linthicum, 1981; Linthicum, 1988). Identified females were incubated individually in tulle-covered, $30 \mathrm{ml}$ vials that contained moist filter paper for oviposition. After allowing seven days for oviposition, surviving females were dissected and the number of retained eggs (= stage $V$ follicles of Christophers (1911)) was counted. Fecundity was recorded as the sum of oviposited and retained eggs. As an index of adult size, the length of one wing of the sacrificed female was measured from the base of the costa to the wing margin, excluding fringes.

Embryonated eggs from field-collected females were hatched in distilled water. Larvae were fed a finely ground mixture of $50 \%$ yeast, $50 \%$ liver powder sprinkled daily on the water surface. The metal rearing trays $25 \times 38 \times 6 \mathrm{~cm}$ were kept covered to prevent evaporation, and the feeding regimen adjusted to maximize growth without fouling the water. At $25-27^{\circ} \mathrm{C}$, pupation occurred 7-10 days after hatch. Adults were allowed to eclose in screened 0.007 or $0.030 \mathrm{~m}^{3}$ cages where they were either deprived of nutrients or had ad libitum access to a $10 \%$ sucrose solution for 2-3 days. The sugar solution was withdrawn $24 \mathrm{~h}$ before blood feeding.

Blood meal weights and fecundities - Blood meal size was determined gravimetrically as the difference between female weights immediately before and after engorgement. Each adult was lightly anesthetized in an individual vial and weighed to the nearest $0.01 \mathrm{mg}$ on a Cahn electrobalance. After a 90-minute recovery period, the female was exposed through tulle to the skin of one of the authors and allowed to feed to repletion. Mosquitoes that did not imbibe blood within five minutes after exposure were not used. Approximately $30 \mathrm{~min}$ after engorgement, each female was again lightly narcotized and weighed. Between the initiation of blood-feeding and re-weighing, most females excreted one or two droplets of lightly colored fluid, which consequently was excluded from calculated blood meal weights. For three species of Nyssorhynchus, including $A$. nuneztovari, the average weight of excreted fluid was from 35 to $57 \%$ of the average weight of total blood ingested (Perez de Valderrama \& Scorza, 1976). These authors did not de- 
monstrate significant differences between species in amount of excreted fluid.

In one experiment, sugar-deprived $A$. nuneztovari were allowed to engorge twice on days two and four after emergence, and blood meal weights were determined gravimetrically after both feeds. These females were dissected 4-5 days after the second feed to record retained eggs.

Since $F_{1}$ females were not inseminated, oviposition rarely occurred and fecundities were recorded as the number of stage $\mathrm{V}$ follicles in ovaries dissected from females maintained at $25.27^{\circ} \mathrm{C}$ for 4.5 days after the blood meal.

Blood meal size and parity - A field experjment, conducted to measure blood meal sizes of $A$. nuneztovari under semi-natural conditions, was repeated four times in Guaquitas, once in each of the months June, July, September and October. On each occasion, 150 to 200 hostseeking females were captured between 1900 and $2300 \mathrm{~h}$ at human bait, but prohibited from imbibing blood. These mosquitoes were maintained without access to sugar at densities of 15.20 per 0.5 .1 , humidified cup until the following night. On one occasion, females in cups were lightly chloroformed to obtain specific identifications, but this practice was discontinued due to mortality and subsequent reduced blood-feeding.

At $2000 \mathrm{~h}$ on the night after capture, approximately one-half of the females were released inside an experimental hut $(2.8 \times 4.0$ X $6.7 \mathrm{~m}$ ) covered by a curtain-net (Elliot, 1972; Bown et al., 1986) that prevented the escape of exophilic mosquitoes after blood-feeding. Four humans seated in the un-lit hut allowed the released mosquitoes to feed to repletion and disperse. From $2045 \mathrm{~h}$ until $2100 \mathrm{~h}$, females resting on the inside of the net or on the walls of the hut were located with flashlights and captured with aspirators. At $2100 \mathrm{~h}$, the collectors were reseated in the hut, and the procedure was repeated with the remaining mosquitoes.

Females in 0.5-1 cups were transported in a cooler to the field station where they were weighed to the nearest $0.01 \mathrm{mg}$ within $3 \mathrm{~h}$ after engorgement. Narcotized females were identified to species, and the length of one wing was measured. Ovaries were dissected immediately and allowed to dry on a microscope slide for subsequent determination of parity by the tracheolar skeining method (Detinova, 1962). Females with ovaries developed beyond stage IIb of Christophers (1911) were excluded from determinations of parity.

Insemination rates - The incidence of insemination among $\boldsymbol{A}$. nuneztovari collected October 15, 1989 from human bait at Guaquitas was measured by the presence or absence of sperm in dissected spermathecae viewed under a compound microscope.

Data analyses - Two-sample comparisons of means were made with t-tests on unpaired data; an approximate t-tes, $t$ ', was used when variances were unequal (Steel \& Torrie, 1960). When more than two samples were compared, data were treated by single classification analysis of variance (ANOVA) followed by a multiple means comparison $(\alpha=0.05)$ with Duncan's Multiple Range Test (DMRT) run on the GLM procedure of SAS (1985). No data transformations were used to equalize variances since ANOVA is robust to heteroscedasticity (Scheffe, 1959). Frequencies were compared with G-tests, using Williams' correction (Sokal \& Rohlf 1981).

\section{RESULTS}

Fecundities of field-collected mosquitoes Host-seeking $A$. nuneztovari and $A$. marajoara caught between November 1988 and early January 1.989 at Guaquitas and in June 1989 at El Achote developed, respectively, means of 140.3 and 142.8 eggs (Table I). These values are significantly greater than the 76.2-egg average fecundity of $A$. triannulatus, which is a smaller species (Table I).

The fecundities of $A$. nuneztovari from $\mathrm{El}$ Achote not given sugar after blood $(n=26)$ were compared to those of other females from the same collection site and date which had continuous access to a $10 \%$ sugar solution $(\mathrm{n}=25)$ after engorgement. The mean fecundities with sugar (128.7 \pm 33.9 sd) and without $(139.1 \pm 18.4 \mathrm{sd})$ were not significantly different $\left(t^{\prime}=1.36, P=0.18\right)$. A high percentage of females developed eggs with post-blood sugar $(96.4 \%)$ and without $(90.3 \%)$. However, the proportion of females surviving seven days was significantly greater with sugar $(57.8 \%)$ than without $(31.4 \%)(\mathrm{G}=4.65, \mathrm{P}<0.05)$ as was 
TABLE I

Number of eggs matured by females ${ }^{1}$ caught at human bait bet ween November 1988 and June 1989 at Guaquitas and El Achote, Venezuela

\begin{tabular}{lccc}
\hline Species & $\mathrm{n}$ & $\begin{array}{c}\text { Mean }{ }^{2} \text { wing } \\
\text { length in } \\
\text { mm }(\mathrm{sd})\end{array}$ & $\begin{array}{c}\text { Mean total eggs } \\
\text { developed } \\
\text { (sd) }\end{array}$ \\
\hline $\begin{array}{l}\text { A. nuneztovari } \\
\text { A. marajoara }\end{array}$ & 71 & $2.87(0.15) \mathrm{a}$ & $140.3(32.2) \mathrm{c}$ \\
A. triannulatus & 30 & $2.90(0.18) \mathrm{a}$ & $142.8(44.5) \mathrm{c}$ \\
& 10 & $2.49(0.10) \mathrm{b}$ & $76.2(23.0) \mathrm{d}$ \\
& & $\mathrm{F}_{(2,108)}=29.31$, & $\mathrm{F}_{(2,108)}=15.36$, \\
& & $\mathbf{P}^{2}=0.001$, & $\mathbf{P}<0.001$, \\
$\mathbf{R}^{2}=0.221$
\end{tabular}

1 : includes only females which matured some egg; no sugar given after blood.

2: means followed by different letters are significantly different according to DMRT after ANOVA;

F: statistics reported at bottom of columns.

TABLE II

Egg development by laboratory-reared, sugar-deprived Nyssorhynchus given one blood meal

\begin{tabular}{|c|c|c|c|c|c|c|}
\hline \multirow{2}{*}{ Species } & \multirow{2}{*}{$\mathbf{n}$} & \multirow{2}{*}{$\begin{array}{c}\text { Mean }^{1} \text { wing } \\
\text { length in } \\
\mathrm{mm}(\mathrm{sd})\end{array}$} & \multicolumn{2}{|c|}{ Mean wt. in $\mathrm{mg}(\mathrm{sd})$} & \multirow{2}{*}{$\begin{array}{c}\% \\
\text { with } \\
\text { eggs }\end{array}$} & \multirow{2}{*}{$\begin{array}{l}\text { No. of eggs } \\
\text { eggs (sd) from } \\
\text { pos. females }\end{array}$} \\
\hline & & & before blood & blood meal & & \\
\hline A. nuneztovari & 47 & $2.91(0.19) \mathrm{a}$ & $1.43(0.33) \mathrm{a}$ & $0.97(0.51) \mathrm{a}$ & 25.5 & $96.3(35.1) \mathrm{ab}$ \\
\hline A. marajoara & 27 & $2.96(0.16) \mathrm{a}$ & $1.42(0.27) \mathrm{a}$ & $1.77(0.61) \mathrm{b}$ & 66.7 & $109.2(26.7) \mathrm{ab}$ \\
\hline A. triannulatus & 13 & $2.51(0.10) \mathrm{b}$ & $0.90(0.12) \mathrm{b}$ & $1.09(0.41) \mathrm{a}$ & 69.2 & $87.7(13.7) b$ \\
\hline \multirow[t]{3}{*}{ A. aquasalis } & 11 & $2.99(0.12) \mathrm{a}$ & $1.28(0.14) \mathrm{a}$ & $2.10(0.75) \mathrm{b}$ & 72.7 & $121.5(29.6) \mathrm{a}$ \\
\hline & & $F_{(3,88)}=22.35$ & $F_{(3,94)}=13.39$ & $F_{(3.94)}=19.84$ & \multirow{2}{*}{\multicolumn{2}{|c|}{$\begin{array}{c}F_{(3,34)}=2.54 \\
P=0.069 \\
R^{2}=0.150\end{array}$}} \\
\hline & & $\begin{array}{l}\mathbf{P}<0.001 \\
\mathbf{R}^{2}=0.432\end{array}$ & $\begin{array}{l}\mathbf{P}<0.001 \\
\mathbf{R}^{2}=0.299\end{array}$ & $\begin{array}{l}\mathbf{P}<0.001 \\
\mathbf{R}^{2}=0.388\end{array}$ & & \\
\hline
\end{tabular}

1 : means followed by different letters are significantly different according to DMRT after ANOVA.

$f:$ statistics reported at bottom of columns.

\section{TABLE III}

$2 \times 2$ tests for independence of egg development from relative blood meal weight ${ }^{1}$

\begin{tabular}{|c|c|c|c|}
\hline Species & pre-blood sugar & G & $\mathbf{P}$ \\
\hline A. nuneztovari & -- & 3.423 & $>0.05$ \\
\hline A. marajoara & -- & 0.071 & $>0.5$ \\
\hline A. nuneztovari & + & 35.84 & $<0.001$ \\
\hline A. aquasalis & + & 0.953 & $>0.1$ \\
\hline A. nuneztovari ${ }^{2}$ & -- & 9.643 & $<0.01$ \\
\hline
\end{tabular}

1: presence or absence of mature eggs compared between females with less than vs more than average relative blood meal weight : data from Fig. 1, except for below.

2: females which took blood twice (on days 2 and 4 after emergence). Relative blood meal weight calculated from total blood taken divided by weight before first feed. 


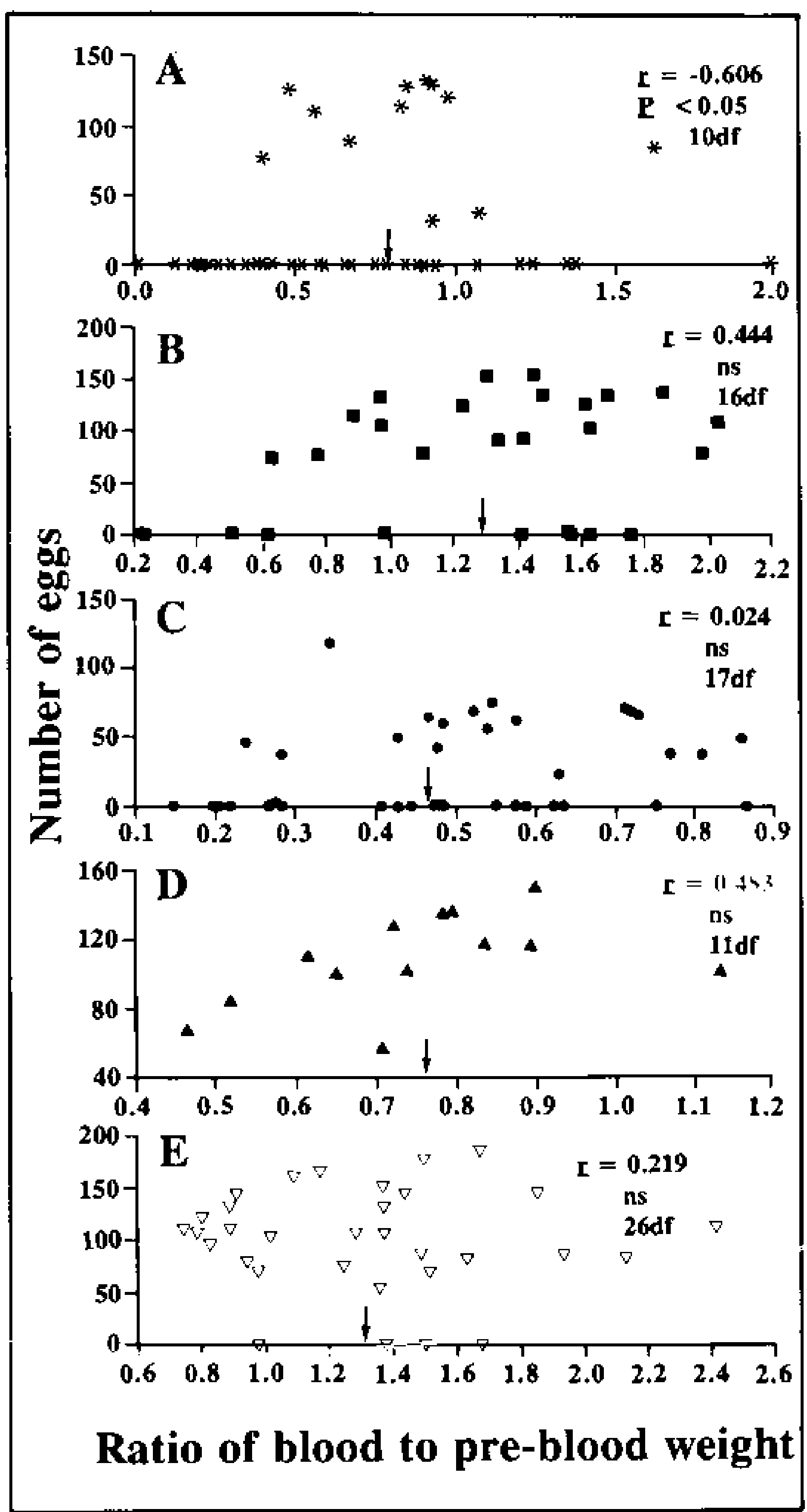

Relationships between number of eggs developed and relative blood meal size. A: sugar-deprived Anopheles nuneztovari. B: sugar-deprived $A$. marajoara. C: sugarfed $A$.nunez to vari. D: sugar-fed $A$. marajoara. E: sugarfed $A$. aquasalis. Arrows indicate mean relative blood meal sizes. Product-moment $r$ calculated only for nonzero y values.

the proportion with retained eggs among gravid females with sugar $(80.0 \%)$ compared to without $(15.4 \%)(\mathrm{G}=23.18, \mathrm{P}<0.001)$.

Blood-meal size and fecundity of sugardeprived $F_{1} s$ - Sugar-deprived $A$. nuneztovari consumed an average amount of blood weighing only $54.8 \%$ of that taken by comparable-sized $A$. marajoara and $46.2 \%$ of that taken by comparable-sized $A$. aquasalis (Table II). Although the mean blood meal weight of $A$. triannulatus was significantly smaller than those of $A$. marajoara and $A$. aquasalis (Table II), the ratios of mean blood meal to mean pre-blood weights for these three species were 1.8 to 2.4 times that for $A$. nuneztovari. Accordingly, two-thirds or more of the $A$. triannulatus, $A$. marajoara and $A$. aquasalis developed eggs, but only slightly more than one-quarter of the A. nuneztovari. Among the females that developed eggs, the average fecundities of $A$. nuneztovari and $A$. marajoara did not differ, although $A$. triannulatus matured significantly fewer eggs than $A$. aquasalis (Table II). However, compared to field-collected counterparts (Table I), significantly fewer eggs were developed by $A$. nuneztovari $(\mathrm{t}=4.31$, $P<0.001,81 \mathrm{df})$ and $A$. marajoara $\quad\left(\mathrm{t}^{\prime}=3,26\right.$, $\mathrm{P}=0.002, \mathrm{ca} 46 \mathrm{df}$ ), although no difference was detected between field-collected and lab-reared $A$. triannulatus $(\mathrm{t}=1.03, P=0.32$, 17 df). Among females that developed some eggs, $A$. nuneztovari exhibited a negative correlation between fecundity and relative blood meal size, but no correlation was evident for A. marajoara (Fig. 1A, B). For both species, the probability of a female developing some eggs was independent of whether the relative size of the blood meal was lesser or greater than the mean (Table III).

Two blood meals, administered on days two and four after emergence, did not significantly increase the proportion of $A$. nuneztovari that matured eggs (Table IV) compared to females that consumed blood only once (Table II) $(\mathrm{G}=0.74,0.50>P>0.10)$. The difference in mean fecundities between gravid females that took blood twice (112.0 eggs) and once ( 96.3 eggs) was not significant ( $\mathrm{t}=1.27, P=0.216$, $22 \mathrm{df})$. Weights of first $(1.16 \mathrm{mg})$ and second $(0.97 \mathrm{mg}$ ) meals taken by $A$. nuneztovari were significantly different $(\mathrm{t}=2.19, P=0.03$, $68 \mathrm{df}$ ). Among $A$. nuneztovari that fed twice, females consuming more than the mean blood weight (both meals combined) had a significantly higher probability of maturing some eggs (Table III).

Blood-meal size and fecundity of sugar-fed $F_{1} s$ - When $A$. nuneztovari females were allowed access to sugar prior to blood, the percentage developing eggs increased to $44.2 \%$ (Table V), but this proportion was not significantly different from the $25.5 \%$ that developed eggs without sugar $(\mathrm{G}=3.48,0.1>\mathrm{P}>0.05)$. However, $100 \%$ of the sugar-fed $A$. marajoara and $A$. triannulatus developed eggs (Table V), a proportion in each case significantly higher than obtained by the sugar-deprived individuals 
TABLE IV

Egg development of laboratory-reared, sugar-deprived Anopheles nuneztovari given two blood meals

\begin{tabular}{ccccccc}
\hline $\mathrm{N}$ & $\begin{array}{c}\text { Mean wing } \\
\text { length in } \\
\text { mm (sd) }\end{array}$ & before blood & first meal & second meal & $\begin{array}{c}\% \\
\text { with } \\
\text { eggs }\end{array}$ & $\begin{array}{c}\text { Mean no. eggs } \\
\text { eggs (sd) } \\
\text { from pos. females }\end{array}$ \\
\hline 35 & $2.99(0.14)$ & $1.39(0.27)$ & $1.16(0.33)$ & $0.97(0.39)$ & 34.3 & $112.0(24.2)$ \\
\hline
\end{tabular}

TABLE V

Egg development by laboratory-reared, sugar-fed $N y$ ssorhynchus given one blood meal

\begin{tabular}{|c|c|c|c|c|c|c|}
\hline \multirow{2}{*}{ Species } & \multirow{2}{*}{$\mathbf{n}$} & \multirow{2}{*}{$\begin{array}{l}\text { Mean }{ }^{1} \text { wing } \\
\text { length in } \\
\text { mm (sd) }\end{array}$} & \multicolumn{2}{|c|}{ Mean wt. in $\mathrm{mg}$ (sd) } & \multirow{2}{*}{$\begin{array}{l}\% \\
\text { with } \\
\text { eggs }\end{array}$} & \multirow{2}{*}{$\begin{array}{l}\text { No. of eggs } \\
\text { (sd) from } \\
\text { pos. females }\end{array}$} \\
\hline & & & before blood & blood meal & & \\
\hline A. nuneztovari & 43 & $2.86(0.13) \mathrm{a}$ & $1.76(0.39) \mathrm{ab}$ & $0.79(0.31) \mathrm{c}$ & 44.2 & $52.7(23.7) \mathrm{b}$ \\
\hline A. marajoara & 13 & $2.90(0.13) \mathbf{a}$ & $2.01(0.42) \mathrm{a}$ & $1.48(0.33) \mathrm{b}$ & 100.0 & $106.8(26.9) \mathrm{a}$ \\
\hline A. triannulatus & 5 & $2.55(0.08) \mathrm{b}$ & $1.14(0.17) \mathrm{c}$ & $1.04(0.46) \mathrm{c}$ & 100.0 & $73.4(22.8) \mathrm{b}$ \\
\hline \multirow[t]{3}{*}{ A. aquasalis } & 32 & $2.96(0.12) \mathrm{a}$ & $1.62(0.30) \mathrm{b}$ & $2.06(0.53) \mathrm{a}$ & 87.5 & $115.2(35.2) \mathrm{a}$ \\
\hline & & $F_{(3,85)}=17,24$ & $F_{(3,90)}=7.96$ & $F_{(3,90)}=61.18$ & \multirow{2}{*}{\multicolumn{2}{|c|}{$\begin{array}{c}F_{(3,61)}=18.31 \\
P<0.001 \\
R^{2}=0.474\end{array}$}} \\
\hline & & $\begin{array}{l}\mathrm{P}<0.001 \\
\mathrm{R}^{2}=0.378\end{array}$ & $\begin{array}{l}\mathrm{P}<0.001 \\
\mathrm{R}^{2}=0.210\end{array}$ & $\begin{array}{l}\mathrm{P}<0.001 \\
\mathrm{R}^{2}=0.671\end{array}$ & & \\
\hline
\end{tabular}

1: means followed by different letters are significantly different according to DMRT after ANOVA.

$\mathrm{F}$ : statistics reported at bottom of columns.

\section{TABLE VI}

Anopheles nuneztovari recaptured after release and blood engorgement in an experimental hut at Guaquitas, Venezuela

\begin{tabular}{|c|c|c|c|c|c|c|}
\hline \multirow{2}{*}{$\begin{array}{l}\text { Date of } \\
\text { experiment }\end{array}$} & \multirow[b]{2}{*}{$\mathbf{n}$} & \multicolumn{2}{|c|}{ Nulliparous recaptures } & \multirow[b]{2}{*}{$\mathrm{n}$} & \multicolumn{2}{|c|}{ Parous recaptures } \\
\hline & & $\begin{array}{l}\text { Mean wing length } \\
\text { in } \mathrm{mm} \text { (sd) }\end{array}$ & $\begin{array}{l}\text { Mean wt. } \\
\text { in } \mathrm{mg}(\mathrm{sd})\end{array}$ & & $\begin{array}{l}\text { Mean wing length } \\
\text { in } \mathrm{mm} \text { (sd) }\end{array}$ & $\begin{array}{l}\text { Mean wt. } \\
\text { in } \mathrm{mg} \text { (sd) }\end{array}$ \\
\hline $30 / \mathrm{V} 1 / 89$ & 13 & $2.85(0.10)$ & $2.39(0.26)$ & $18\}$ & $2.83(0.15)$ & $2.83(0.57)$ \\
\hline $8 /$ V111/89 & 7 & & & $2)$ & & \\
\hline $28 / 1 \times / 89$ & 37 & $2.85(0.13)$ & $2.51(0.37)$ & 20 & $2.89(0.12)$ & $2.92(0.52)$ \\
\hline $21 / X / 89$ & 19 & $2.79(0.11)$ & $2.38(0.41)$ & 32 & $2.88(0.11)$ & $2.96(0.57)$ \\
\hline Totals & 76 & $2.84(0.12)$ & $2.44(0.36)$ & 72 & $2.87(0.13)$ & $2.91(0.55)$ \\
\hline
\end{tabular}

of the respective species $(\mathrm{G}=7.23, \mathrm{P}<0.01$; $\mathrm{G}=23.2, \mathrm{P}<0.001)$. For $A$. aquasalis, the percentages of females that matured eggs with pre-blood sugar $(87.5 \%)$ and without $(72.7 \%)$ were not significantly different $(\mathrm{G}=1.20$, $P>0.10)$. Intraspecific comparisons of average fecundities with or without sugar revealed no significant differences except among $A$. nuneztovari, whose mean clutch size dropped to 52.7 eggs per sugar-fed female $(\mathrm{t}=4.14, P<0.001$, 29 df). Correlations between fecundity and relative blood meal size were not significant for sugar-fed $A$. nuneztovari, $A$. marajoara or A. aquasalis (Fig. 1C-E). Only for A. nunez- 
tovari, individuals which consumed more than the average relative blood meal size had a significantly greater chance of developing some eggs (Table III). For all four species, the preblood weight was significantly higher for sugar-fed than for sugar-deprived females (t-tests, $P<0.004$ for all). Although the average blood meal weight of all four species was slightly less for sugar-fed individuals, only the value for $A$. nuneztovari was significant $(\mathrm{t}=$ $2.01, P=0.047,77 \mathrm{df}$ ). Intraspecific comparisons of wing lenghts for the experimental females in Tables II and $V$ revealed no significant differences.

Blood meal weight and parity - There was considerable variation in the rates of parity and of recapture of engorged mosquitoes among experiment dates. Many of the females anesthetized on July 8, 1989 did not take blood that night, so the few engorged females were pooled with individuals from an experimental replicate one week earlier (Table VI). Parity rates among recaptured, engorded $A$. nuneztovari ranged from $35.1 \%$ in late September to $62.7 \%$ slightly more than 3 weeks later. Very few engorged individuals of other $N y$ ssorhynchus (A. marajoara, A. triannulatus and $A$. oswaldoi) were recovered, so only the data for $A$. nuneztovari were analyzed further.

The common trend for all replicates of the experiment was the significantly higher mean weight of engorged parous $(2.91 \mathrm{mg})$ compared to nulliparous $(2.44 \mathrm{mg})$ A. nuneztovari $(\mathrm{t}=$ $6.04, \mathrm{P}<0.001,121 \mathrm{df})$. The mean weight of these nulliparous, engorged females trapped in the field did not differ significantly from the mean weight $(2.55 \mathrm{mg})$ of sugar-fed females engorged in the laboratory (Table $\mathrm{V})(\mathrm{t}=1.20$, $P=0.234$ ). Among the field females, the mean wing lengths of all parous and nulliparous $A$. nuneztovari did not differ significantly $(\mathrm{t}=$ $1.47, \mathrm{P}=0.144)$.

Insemination frequency - Sperm was detected in $96.6 \%$ of $88 \mathrm{~A}$. nuneztovari captured at human bait in Guaquitas the night of October 15, 1989. Among 83 of these individuals suitable for scoring by the tracheolar skeining method, $38.6 \%$ were parous. The average wing lenghts of parous ( $2.85 \mathrm{~mm} \pm 0.12)$ and nulliparous $2.90 \pm 0.11 \mathrm{sd}$ ) females did not differ significantly $(\mathrm{t}=1.74, P=0.09,82 \mathrm{df})$.

\section{DISCUSSION}

Blood meal size and feeding frequency Some of the data support the interpretation that most $A$. nuneztovari from western Venezuela must take two or more blood meals to complete their first ovarian cycle. By contrast, nearly all nulliparous females of the related $A$. marajoara, $A$. triannulatus and $A$. aquasalis matured eggs after one blood feed (Table V).

The apparent requirement of several blood feeds to develop the first egg clutch is associated with smaller meals by $A$. nuneztovari. Nulliparous $A$. aquasalis and $A$. marajoara, species indistinguishable in size from $A$. nuneztovari based on wing lengths, consumed approximately twice as much blood (Tables II, V). These differences in meal sizes, observed in the laboratory in the absence of environmental disturbances such as host defense, appear to be attributable to genetic characteristics of the species or populations. Gillies (1954) reported that small blood meals were a characteristic of the first feed by nulliparous $A$. gambiae (s. 1.) from East Africa.

The selective advantage of foraging behavior that apparently requires several, successive excursions, which expend energy and risk predation, to quest blood for egg development is a mystery. Perhaps in western Venezuela and eastern Colombia where $A$. nuneztovari seek hosts primarily late at night (Elliot, 1968) and blood sources are abundant, the risk of mortality during foraging may be low, especially if the smaller blood meal does not impair flight. Perez de Valderrama \& Scorza (1981) suggested that small blood meals might facilitate the known exophilic behaviour of $A$. nuneztovari because engorded females could fly from shelters immediately after feeding. However, these authors did not demonstrate significant differences in blood meal size between $A$. nuneztovari and the exophagic $A$. darlingi, possibly because their measurements did not distinguish between parous and nulliparous A. nuneztovari.

Because most $A$. gambiae and $A$. culicifacies consume blood before mating, we investigated the possibility that the first blood meal of $A$. nuneztovari might have a prenuptial function independent from the initiation of egg development. However, the high insemination rate (96.6\%) of $A$. nuneztovari at a single night's 
bait catch, coupled with a relatively low concurrent parity rate $(38.6 \%)$, suggested that mating occurs before the first blood feed in most individuals of this species. High insemination rates among females trapped at human bait have also been reported for $A$. aquasalis $(90.2 \%)$ and $A$. albitarsis (= marajoara) $(97.3 \%)$ in Trinidad (Senior White, 1953).

Engorged, parous $A$. nuneztovari weighed significantly more than nulliparous counterparts with similar wing lengths (Table VI). These data indicate that, after laying a first egg batch, $A$. nuneztovari females are no longer constrained to small blood meals. As a corollary, we predict that most parous $A$. nuneztovari should require only one blood meal per egg clutch.

Control of fecundity - The absence of significant, positive correlations between number of eggs developed and relative blood meal size in all laboratory-reared Nyssorhynchus examined (Fig. 1) was unexpected. Strong, positive correlations between blood meal weight and fecundity have been demonstrated for laboratory colonies of $A$. stephensi ( $\mathrm{r}=$ 0.817, 42 df: Reisen \& Emory, 1976) and $A$. quadrimaculatus $(\mathrm{r}=0.883,23 \mathrm{df}: \mathrm{Hu} \&$ Lounibos; unpublished). Although the Nyssorhynchus that we tested were uninseminated $F_{1} s$ from field collections, significant positive correlations between blood meal size and fecundity were obtained from unmated $F_{1} s$ of field-collected $A$. crucians $(\mathrm{r}=0.665,27 \mathrm{df})$ and $A$. atropos ( $\mathrm{r}=0.596,23 \mathrm{df})$ (Hu \& Lounibos, unpublished). El-Akad \& Humphreys (1990) reported no relationship between insemination status and ovarian development in a laboratory colony of $A$. pharoensis.

Working in India, Roy (1940) asserted that insemination was a prerequisite for egg develop. ment of $A$. subpictus, but not of the related $A$. annularis or A. stephensi. Bates (1949) suggested that $A$. superpictus and $A$. maculipennis (s. 1.) from Albania also required sperm to promote egg maturation. Although this phenomenon of "spermathecal stimulation" (Roy, 1940) has not been investigated among Nyssorhynchus, our data demonstrate that insemination is not an absolute requirement for egg development among any of the four species herein studied.

Possibly the positive trends in the fecundity versus blood weight relationships for $A$. marajoara and $A$. aquasalis (Figs $1 \mathrm{~B}, \mathrm{D}, \mathrm{E}$ ) would become significant with larger sample sizes. For A. nuneztovari there is clear evidence that blood meals larger than the mean size increase the probability of egg maturation (Table III). Meanwhile, the significant negative correlation for sugar-deprived A. nuneztovari (Fig. 1A) and the decrease in mean fecundity of sugar-fed females of the same species (Table II cf. Table V) are difficult to explain.

We conjecture that the decrease in fecundity of the sugar-fed $A$. nuneztovari may be related to host sensitization and production of immunological factors such as are known to suppress fecundity and survival of other species of mosquitoes (e.g., Reisen \& Emory, 1976). Our first experiments on Nyssorhynchus, which used one author (LPL) as the predominant blood source, were performed on sugar-deprived A. nuneztovari, which matured a mean of 96.3 eggs. The sugar-fed females, which developed a mean of 52.7 eggs, were characterized six months later. During the intervening period the senior author frequently fed wild-caught and lab-reared $A$, nuneztovari, but other species only infrequently, on his blood. Reisen \& Emory (1976) reported that $A$. stephensi feeding from a sensitized human matured 59.8 eggs per female compared to 117.0 eggs per female on an immunologically naive host, an approximately two-fold fecundity difference as observed between the two groups of $A$. nuneztovari.

For both $A$. nuneztovari and $A$. marajoara, the average fecundity of females trapped at human bait in the field was significantly greater than that os gravid, laboratory-reared females (Table I cf. Tables I, V). Before imbibing from collectors, the field females had an unknown feeding history. Since mosquito fecundity is affected by the nutritional quality of the host (e.g. Shelton, 1972), the field females may have fed formerly on a nutritionally superior blood source. On the other hand, the clutch size of parous females is usually less than that of nulliparous females for most Anopheles (e.g., Detinova, 1962), a pattern not consistent with the discrepancy in fecundities between field and laboratory $A$. nuneztovari and $A$. marajoa$r a$. Scorza et al. (1981) observed no significant differences in the sizes of first $(\bar{x}=95.3)$ and second $(\overrightarrow{\mathrm{x}}=89.3)$ egg batches of laboratoryreared $A$. nuneztovari.

The high percentages $(90.3 \%$ and $96.4 \%)$ of field-collected $A$. nuneztovar $i$ that matured eggs 
after one engorgement may also seem at variance with the hypothesis that nulliparous females need two or more blood meals to develop eggs. However, these females came from a single night's catch at El Achote during the dry season when the incidence of parity may have been high.

Aspects of A. nuneztovari survival - The few parity estimates of $A$. nuneztovari samples in this study ranged from 35 to $63 \%$, which are within the spectrum of variation observed in more extensive data on this population (Rubio, unpublished). This broad range in variation occurred in two collections made approximately three weeks apart (Table VI), suggesting rapid turnover in the age structure of host-seeking populations and underscoring the limitations of the parity rate formula (Davidson, 1954) for estimating survivorship. Since ovaries developed beyond stage II cannot be scored by the tracheolar skeining method, we may have underestimated the true parity rates of $A$. nuneztovari by approximately $5 \%$ (Charlwood, 1980).

Size variation in female $A$. nuneztovari, as reflected by the constancy of wing lengths and their low standard deviations (Tables I-II, IV-VI), was slight compared to many other species of mosquitoes (Fish, 1985) and showed no seasonal variation (Lounibos \& Conn, unpublished). The lack of significant differences in wing lengths between parous and nulliparous samples (Table VI), suggests that, at this level of resolution, there is no evidence for sizedependent survivorship.

The importance of sugar for post-blood meal survival was documented here for $A$. nunezto$v a r i$, as it has been for many mosquito species (e. g., Nayar \& Sauerman, 1975). The effect of sugar on egg retention is also well known. The absence of an effect of post-blood sugar on fecundity would be expected if clutch size is determined earlier during adult alimentary history.

\section{ACKNOWLEDGEMENTS}

To Y. Rubio for the invitation to collaborate and access to facilities and unpublished data; $R$. Alvarado, J. Amson, J. Berti, N. Delgado, the family of Sra. Rosa, the Division of Malariology, C. Machado-Allison, the Pan American Health Organization, Y. Rangél, R. Zimmerman and the many 'cebos' who donated blood for logistical and technical support in Venezuela; R. Escher and G. Hu for rearing mosquitoes and counting eggs in Florida. Constructive comments by J. Linley, G. O'Meara and, especially, W. Foster improved the manuscript.

\section{REFERENCES}

ARRUDA, M. D.; CARVALHO, M. B.; NUSSENZWEIG, R. S.; MARACIC, M.; FERREIRA, A. W. \& COCHRANE, A. H., 1986. Potential vectors of malaria and their differential susceptibility to Plasmodium falciparum and Plasmodium vivax in northern Brazil identified by immunoassay. $A m$. J. Trop. Med. Hyg., 35:873-881.

BATES, M., 1949. The natural history of mosquitos. MacMillan Co., New York, 378 p.

BOWN, D. N.; RIOS, J. R.; FREDERICKSON, C.; CABANAS, G. D. A. \& MENDEZ, J. F., 1986. Use of an exterior curtain-net to evaluate insecticide/mosquito behavior in houses. J. Am. Mosq. Control Assoc., 2: 99-101.

BRENGUES, J. \& COZ, J., 1973. Quelques aspects fondamentaux de la biologie d'Anopheles gambiae Giles (Sp. A.) et d'Anopheles funestus Giles, en zone de savane humide d'Afrique de l'Ouest. Cah. O. R. S. T. O. M. Ser. Ent. Med. et Parasit., 11: 107-126.

BURKOT, T. R., 1988. Non-randon host selection by anopheline mosquitoes. Parasitol. Today, 4: 156162.

CHARLWOOD, J. D., 1980. Observations on the bionomics of Anopheles darlingi Root (Diptera: Culicidae) from Brazil. Bull. Ent. Res., 70: 685-' 692.

CHRISTOPHERS, S. R., 1911. The development of the egg follicle in Anophelines. Paludism, 2:73-88.

DAVIDSON, G., 1954. Estimation of the survival rate of anopheline mosquitoes in nature. Nature, 174: $792-793$.

DETINOV.A, T. S., 1962. Age-grouping methods in Diptera of medical importance. W. H. O. Geneva, $216 \mathrm{p}$.

EL-AKAD, A. S. \& HUMPHREYS, J. G., 1990. Effects of larval and adult diet plus mating/insemination upon ovarian development of laboratoryreared Anopheles pharoensis in Egypt. J. Am. Mosq. Control Assoc., 6: 96-98.

ELLIOT, R., 1968. Studies on man-vector contact in some malarious areas in Colombia. Bull.W. H. O., 38: 239-253.

ELLIOT, R., 1972. The influence of vector behavior on malaria transmission. Am. J. Trop. Med. Hyg., $21: 755-763$.

FARAN, M. E., 1980. Mosquito studies (Diptera, Culicidae) XXXIV. A revision of the Albimanus Section of the subgenus Nyssorhynchus of Anopheles. Contrib. Am. Entomol. Inst., 15: 1-215.

FARAN, M. E. \& LINTHICUM, K. J., 1981. A handbook of the Amazonian species of Anopheles (Nyssorhynchus) (Diptera: Culicidae). Mosq. Syst., 13: $1-81$.

FISH, D., 1985. Analysis of adult size variation within natural mosquito populations, p. 419-430. In L. P. Lounibos, J. R. Rey \& J. H. Frank (eds), Ecology of mosquitoes: proceedings of a workshop. 
Florida Medical Entomology Laboratory, Vero Beach, USA.

GABALDON, A., 1981. Anopheles nuneztovari: important vector y agente de malaria refractaria en Venezuela. Bol. Dir. Malar. San. Amb., 21: 28-38.

GILLIES, M. T., 1954. The recognition of age-groups within populations of Anopheles gambiae by the pre-gravid rate and the sporozoite rate. Ann. Trop. Med. Parasit., 48: 58-74.

GRIMSTAD, P. R. \& HARAMIS, L. D., 1984. Aedes triseriatus (Diptera: Culicidae) and La Crosse virus. III. Fnhanced oral transmission by nutritiondeprived mosquitoes. J. Med. Entomol., 21: 249 256

HAMON, J. J.; MOUCHET, J.; BRENGUES, J. \& CHAUVET, G., 1970. Problems facing anopheline vector control. Vector ecology and behavior, during and after application of control measures. Entomol. Soc. Am. Misc. Publ., 7:28-41.

LINTHICUM, K. J., 1988. A revision of the Argyritarsis Section of the subgenus Nysshorhynchus of Anopheles (Diptera: Culicidae). Mosq. Syst., 20: 98-271.

MACDONALD, G., 1957. The epidemiology and control of malaria. Oxford Press, London, $201 \mathrm{p}$.

MOLINEAUX, L. \& GRAMICCIA, G., 1980. The Garki Project. W. H. O., Geneva, 311 p.

NAYAR, J. K. \& SAUERMAN, D. M., 1975. The effects of nutrition on survival and fecundity in Florida mosquitoes. Part I. Utilization of sugar for survival. J. Med. Entomol., 12:92-98.

PEREZ DE VALDERRAMA, M. \& SCORZA, J. V., 1976. Experimentos e indagaciones para explicar el comportamiento evasivo de Anopheles nuneztovari Gabaldon, 1940 de Venezuela. Bol. Dir. Malar. San. Amb., I6:212-220.

PONNUDURAl, T.; LANSEN, A. H. W.; VAN GE-
MERT, G. J. A.; BENSINK, M. P. E.; BOLMER, M. \& MEUWISSEN, J. H. E. TH., 1989. Sporozoite load of mosquitoes infected with Plasmodium falciparum. Trans. R. Soc. Trop. Med. Hyg., 83: 67.70 .

REISEN, W. K. \& ASLAMKHAN, M., 1976. Observations on the swarming and mating behaviour of Anopheles culicifacies Giles in nature. Bull. W.H.O., 54: 155-158.

REISEN, W. K. \& EMORY, R. W., 1976. Blood feeding of Anopheles stephensi. Ann. Ent. Soc. Am., 69: 293-298.

ROY, D. N., 1940. Influence of spermathecal stimulation on the physiological activities of Anopheles subpictus. Nature, 145:747-748.

SAS, 1985. SAS User's Guide: Statistics. Version 5 ed. SAS Institute, Cary, North Carolina, USA. xvi + $957 \mathrm{p}$.

SCHEFFE, H., 1959. The analysis of variance. J. Wiley \& Sons, New York, USA.

SCORZA, J. V.; RODRIGUES, E. \& MORENO, G., 1981. Ecologia poblacional de Anopheles nuneztovari Gabaldon, 1940 en el occidente de Venezuela. Bol. Dir. Malariol. San. Amb., 21:1-27.

SENIOR WHITE, R. A., 1953. On the evening biting activity of three neotropical Anopheles in Trinidad, British West Indies. Bull. Ent. Res., 44: 451. 460.

SHELTON, R. M., 1972. The effects of blood source and quantity on production of eggs by Culex salinarius Coquillett (Diptera: Culicidae). Mosq. News, 32: 31-37.

SOKAL, R. R. \& ROHLF, F. J., 1981. Biometry. 2nd ed. W. H. Freeman, San Francisco, California, USA. xviii +859 p.

STEEL, R. G. D. \& TORRIE, J. H., 1960. Principles and procedures of statistics. McGraw-Hill, New York, USA. xvi +481 p. 